\title{
Offer quality affecting consumption of hospitality products and services in franchised restaurants in Nairobi Central Business district Kenya
}

\author{
Gitau Annie Wambui ${ }^{{ }^{*}}$, Kibe Judy ${ }^{2}$, Macharia Stephen ${ }^{1}$ \\ ${ }^{1}$ Karatina University, School of Business, Kenya \\ ${ }^{2}$ Moi University, School of Tourism Management, Kenya
}

\begin{abstract}
The fast-food concept seems to attract franchisees and is growing rapidly in Kenya. The purpose of the study was to look into the offer quality affecting consumption of hospitality products and services in franchised restaurants in Nairobi Central Business Kenya. The objective of the study was to explore the extent to which offer quality affect consumption of hospitality products and services to achieve competitive advantage in Franchised Restaurants. The problem being investigated was why the offer quality is favouring some franchises and not others. It focused on food and beverage production and service techniques adopted to increase consumption. The research was carried out in the Nairobi CBD in franchised restaurants. The study adopted the descriptive research design. A census study was done on the 15 restaurants and their 15 managers in the CBD while systematic random sampling was done to select $10 \%$ of 3250 customers. The data was collected by use of questionnaires and interviews. Descriptive and inferential statistics were used for data analysis. The findings revealed that the quality of food and the price greatly influenced the consumption of the products and services.
\end{abstract}

Keywords: food and beverage, products and services, offer components

JEL classification: L83

\section{Uticaj kvaliteta ponude na promet ugostiteljskih prozvoda $i$ usluga $u$ franšiznim restoranima $u$ Centralnoj poslovnoj oblasti Najrobija u Keniji}

Sažetak: Čini se da koncept brze hrane privlači franšize i da se ubrzano razvija u Keniji. Svrha ove studije bila je da se ispita kvalitet ponude koji utiče na promet proizvoda i usluga u ugostiteljskim objektima u Centralnoj poslovnoj oblasti Najrobija u Keniji. Cilj studije je bio da se istraži u kojoj meri kvalitet ponude utiče na promet ugostiteljskih proizvoda i usluga, kako bi se postigla konkurentska prednost u franšiznim restoranima. Glavno pitanje istraživanja je zašto kvalitet ponude favorizuje neke franšize, a druge ne. Istraživanje se fokusira na proizvodnju hrane i pića i uslužne tehnike usvojene u cilju povećanje potrošnje. Istraživanje je sprovedeno u Centralnoj poslovnoj oblasti Najrobija u franšiznim restoranima. Studija je usvojila dizajn deskriptivnog istraživanja. Studija je obuhvatila 15 restorana i 15 menadžera tih restorana u Centralnoj poslovnoj oblasti, dok je sistematsko nasumično uzorkovanje izvršeno kako bi se odabralo $10 \%$ od 3250 korisnika. Podaci su prikupljeni

*anniegitau@gmail.com 
korišćenjem upitnika i intervjua. Za analizu podataka korišćene su deskriptivne i inferencijalne statistike. Nalazi su otkrili da kvalitet hrane i cena uveliko utiču na promet proizvoda i usluga.

Ključne reči: hrana i piće, proizvodi u usluge, komponente ponude JEL klasifikacija: L83

\section{Introduction}

Franchising is a business management strategy which helps businesses to expand and venture into global markets. It allows the use of a hybrid marketing mix strategy. Using a hybrid marketing tactic, the franchisor would provide the overall strategy for running the business but may leave aspects of the business for the franchisee to determine (Gikonyo et al., 2015).

Tactic is the creation of a unique and valuable position, which usually involves different sets of activities. Tactic also refers to the ideas, plans and support that firms employ so as to compete successfully against their rivals. The main focus of tactical positioning is to choose activities that yield superior profitability and thus create a sustainable competitive advantage against rivals (Munyaka, 2016).

Organizations aiming to survive in a turbulent environment must come up with strategies that guide their decisions. To survive in the market, organizations adopt various tactics in the face of competition and also to ensure success. Some organizations strive to improve their performance and market standing by achieving lower costs than rivals, while other pursue product superiority or personalized customer service or development of competencies or capabilities that the rivals cannot match. This sets it apart from rivals, builds customer loyalty and achieves a sustainable competitive advantage (Wambura, 2012).

The fast-food concept seems to attract franchisees mostly as a result of high viability of the business and the positive cash flow that comes faster from franchises than from independent businesses (Mendelsohn, 2004). Nicholas and Quinn (2002) observed that the largest fastfood companies are involved with franchising.

The United States are considered as home of franchising, has developed to maturity, plays a key role in the business activities that contribute significantly to that economy (Gikonyo et al, 2015). Nineteen years ago the first foreign fast food chains Steers and Debonairs Pizza were launched in Nairobi Kenya (Estelle, 2016). Generally, the most successful franchises are closly related to the food, restaurant and beverages industries. Kenyans are spending more time and money eating out or ordering, so fast food industry has benefited greatly as a result (George, 2016).

American franchises such as KFC and Naked Pizza have begun to pop up in Nairobi, Kenya. Given the establishment of the counties, investment prospects outside of Nairobi are likely to emerge in the coming years (Malinda, 2013). The Kenchic Inn is such a chain. It was the largest fast food chain to franchise fried chicken restaurants and sometimes referred to as Kenya's answer to KFC.

The Kenchic Inn is owned by Kenchic Ltd. which is one of the largest poultry producers and distributors in Africa. Michira (2016) says that it has unfortunately stopped its eatery business due to the fast food market rapidly evolving, causing a gradual drop in the number of Kenchic Inn-branded outlets in Kenya. In an interview with The Standard Digital, a Kenchic official said "We have been unable to maintain the standards that we would desire as a company. When you have customers complaining of bad food, you can guess what that does to our brand," (Michira, 2016). Kenchic Inn outlets have set minimum standards 
required in terms of quality, but the firm has been unable to ensure the specifications are met leading to dwindling image among customers, despite a reduction in their prices (Michira, $\underline{2016}$.

Gavin Bell was hired to oversee the setup of the KFC franchisee in 2011 when they entered the Kenyan market, but he is quitting KFC to rebuild his brand Kengeles Bar and Restaurant, a chain that has fallen from nine outlets to one. Kengeles, which was built 16 years ago, has suffered massive losses due to changes in its business model. He looks forward to utilize the lessons he learned while running KFC (Mulupi, 2014).

While at the peak of success, Kengeles was franchised to nine restaurants with a manager, appointed by the owner, Bell, to oversee them. He stated that "franchising can be a good business model when done properly but running one's own local business and applying lessons from international franchise systems to professionalize your brand can be effective". Bell cites the case of Kenya's leading coffee chain Java House, whose owners run it themselves by copying the principles of a franchise (Mulupi, 2014).

Over the recent years there has been an upsurge of fast food franchises setting shop in Nairobi with the aim of bringing international food quality standards (Wanja, 2015). African franchisees are supposed to maintain sufficient supplies of the products that drive their businesses and the said products must meet the franchisor's set quality standards. Case in point, KFC among other fast food brands requires adequate supplies of chicken that meet their specifications. This may be difficult to achieve in some African countries where supply of chickens from local chicken farmers does not meet the franchisor's criteria for food safety and security and quality and quantity (Tyre \& Han, 2015).

International chains are still reluctant to franchise, because of the difficulties in maintaining brand standards when they are not in management control. The brand owners can only guarantee standards if they are in control of the management, and the funds are available from the owner to renew or renovate as required. The experience should be the same; they not only have to match quality with their other stores but with the other worldwide outlets as well (Samanani, 2013). Despite these issues, more franchised restaurants are rapidly coming up mostly in Kenya's capital, Nairobi and most recently in the major cities and performing very well despite the increasing competition.

The objective of the study was to explore the extent to which offer quality affects consumption to achieve competitive advantage in Franchised Restaurants. The problem being investigated was why offer quality is favouring some franchises and not others, since some are closing while the rest are opening new branches all over the country. The research question was, to what extent does the quality of hospitality products and services offer affects consumption in franchised restaurants in Kenya's Central Business District in Nairobi, Kenya.

\section{Literature review}

\subsection{Theory of SERVQUAL model}

Parasuraman et al. (1998) developed service quality model which is named SERVQUAL model. The model has five factors which form the acronym RATER, one of which is reliability. This theory stresses customer retention, if the quality standards are observed then the customers will not go to the next competitor. Parasuraman et al. (1988) argue that, with minor modification, SERVQUAL can be adapted to any service organization. They further 
argue that information on service quality gaps can help managers diagnose where performance improvement can best be targeted.

The assumption of the service quality models is that customers' encounter with a service is always with certain prior expectations, which is than matched with the actual experience so as to establish the organization's service quality. Salvador et al. (2007) suggested that value, benefit and cost should be included in the price, and value is received when the cost of purchasing a product or service is less than the benefit obtained from it.

Reliability is ability to perform a promised service or offer a product consistently and accurately. An employee is supposed to perform a task or offer a product consistently so as to assist in customer retention. When an outlet is consistent in the quality of its products and services, there will be repeat customers. A restaurant may use this variable to make its services and products standout from those of its competitors. This will make customers visit that particular restaurant to enjoy that service and product. A customer will pay for good and quality service and products. When good products and excellent service are combined, the customer is happy. This can be achieved by training and retraining the staff on proper customer service, etiquette, service delivery and product preparation methods.

Assurance is knowledge and courtesy of employees and their ability to convey trust and confidence. Service providers are expected to be the experts of the service they're delivering. Communicating the expertise to customers is considered significant, since customers' lack of awareness of service providers' competencies can lead to less confidence in the provider as well as more negative service quality assessment results. Before conducting the work, service providers' expertise and comptences should be communicated to customers in ways such as display industry certifications on patches, badges or buttons worn by employees, include certification logos on emails, letters \& reports, put certifications into posters, newsletters $\&$ handouts. The communication of competencies is important as it contributes to managing customers' expectations and influence their service quality assessment in advance (Arlen, 2008).

Tangibles is appearance of physical facilities, equipment, personnel, and communication materials. The restaurant should not concentrate too much on appearances and fail in other factors (Arlen, 2008). This will include the décor, furniture and all that makes a room look and feel great. Customers may go to an outlet simply because it feels good to sit and be served there. The restaurant can provide a product or service that their rivals cannot and gain power over buyers because they cannot get the same thing from anyone else.

Franchises have products of the same quality, quantity, portion and taste etc. in all similar outlets. The product and service should be the same locally and globally. This can be achieved by coming up with a special food item that the restaurant associated with. It may be a special tasting chicken with a secret recipe or the way they present their food, packaging etc. for instance, when Steers came into the Kenyan market, it was known for including a toy with every child pack of food and that attracted many children.

Empathy is defined as providing caring and individualized attention to company's customers. Services can be performed completely to specifications, yet customers may not feel employees care about them during delivery, which may have a negative effect in the process of assessment carried out by customers. Not only is service delivery important, but also how it is done, which is why employees should undergo a training in which they would learn how to interact with customers, their end-users. Even a brief session during initial orientation helps employees understand their impact on customers' assessment of service quality (Arlen, 2008). A simple greeting or 'how was your meal' makes the customer happy. 
Responsiveness is willingness to help customers and provide prompt service. Respond quickly, promptly, rapidly, immediately and instantly. It is important for customers to feel providers are responsive to their requests and not just emergencies (Arlen, 2008). The food might not be what the customer ordered and a quick response is very welcome. Informing customers why their meal is taking longer than usual and answering their queries promptly will make customers feel they are important.

\subsection{Research variables}

The independent variable was reliability in terms of service delivery, products quality, quantity and price. The dependent variable was Consumption of products and services.

\section{Research methodology}

The researcher used both qualitative and quantitative research method to determine relationships. The study was conducted in the Nairobi Central Business District (NCBD) in Kenya. The study targeted all the 15 Managers of the 15 restaurants in the Nairobi CBD, the average number of customers were 2,050 for foreign and 1,150 for local franchises.

The study adopted a census sampling method on the restaurants as they were not many in the NCBD. All Managers were respondents because they were a small number in the CBD but 325 customers were selected from the 3,250 by systematic random sampling. The study adopted questionnaires and interview guides as instruments. The respondents were asked to indicate the factors that were important in their opinion along a five-point Likert scale.

Table 1: Sample - Foreign Franchises

\begin{tabular}{|l|l|c|c|c|}
\hline & \multicolumn{1}{|c|}{ Restaurant } & Number & Managers & Customers \\
\hline 1. & Pizza Inn & 2 & 2 & 40 \\
\hline 2. & Debonaires Pizza & 2 & 2 & 30 \\
\hline 3. & Subway & 2 & 2 & 25 \\
\hline 4. & Galitos & 2 & 2 & 40 \\
\hline 5. & Steers & 3 & 3 & 50 \\
\hline 6. & KFC & 2 & 2 & 20 \\
\hline & Totals & 11 & 11 & 205 \\
\hline
\end{tabular}

Source: Research data, 2017

Table 2: Sample - Local Franchises

\begin{tabular}{|l|l|c|c|c|}
\hline & Restaurant & Number & Managers & Customers \\
\hline 1. & Kengeles & 1 & 1 & 35 \\
\hline 2. & Highlands & 2 & 2 & 80 \\
\hline & Totals & 3 & 3 & 115 \\
\hline
\end{tabular}

Source: Research data, 2017

\section{Data analysis}

Data analysis was done using descriptive statistics, mainly frequencies, percentages, mean scores, and standard deviation. The results have been presented in table form. Descriptive statistics, correlation and regression analysis were used to analyze the data. The data from the respondents was summarized using frequencies percentages and mean scores. Standard deviation was used to determine whether there were variations in responses of the restaurants being studied. 


\section{Findings of the study}

The research sought to establish information on the respondents used in the study with regards to the age, gender and education level of both the customers and the managers and duration of work in that industry, the number of years the restaurant had been operating in Kenya as well as the number of branches they have in the country.

The results indicate that $62 \%$ of the restaurant managers were male while $38 \%$ of the restaurant managers were female. This indicates that majority of the managers in franchised Restaurants in Nairobi, Kenya are male. They also suggest that, $57.54 \%$ of the restaurant's customers were females while $42.46 \%$ of the restaurant's customers were male which indicates that majority of the customers in franchised Restaurants in Nairobi Kenya are female.

As for the age factor of managers, it was established that $25 \%$ were between 25 to 35 years, $50 \%$ were between $36-45$ years and $25 \%$ were 45 years and above. The findings therefore indicate that most of the restaurant managers in Kenya are between 36-45 years. This being the most active age group, they are involved in management. As for the age category of customers, the study found that $38.77 \%$ were aged between $18-25$ years, $16.62 \%$ were between $25-30$ years, $32.92 \%$ were between $30-45$ years and $11.69 \%$ were $35-40$ years and above. This indicates that most of the customers of franchised restaurants in Nairobi, Kenya are aged 18-25 years.

The study findings on the academic background of managers, indicate that $7.975 \%$ are those who have had four years of secondary school education with a Kenya certificate of secondary education (KCSE), $1.53 \%$ are those who have had six years of secondary school education with a Kenya advanced certificate of education (KACE), 7.055\% are holders of craft certificates, $63.80 \%$ have a diploma certificate, $12.58 \%$ have a higher national diploma certificate, while $4.1 \%$ are university graduates and $3.067 \%$ represent other levels of education. Most of the managers are diploma and higher national diploma certificate holders. As for the academic background of customers, the study findings indicate that $26.15 \%$ of the customers are those who have had six years of secondary school education with a Kenya advanced certificate of education (KACE), $8 \%$ are those who have had four years of secondary school education with a Kenya Certificate of secondary education (KCSE), $22.46 \%$ are craft certificate holders, $32.31 \%$ university graduates, $4.308 \%$ Higher national diploma certificates holders, while $4 \%$ are diplomas certificate holders and $2.769 \%$ represent other levels of education. Most of the customers are university graduates and those who have had six years of secondary school education with a Kenya advanced certificate of education (KCSE).

As for work experience, the findings suggest that $2.5 \%$ of the managers had been managing the business for less than 2 years, $(50 \%)$ which is the majority have run the business for 3-5 years, and $25 \%$ had been there for a period of 6-8 years while and only $12.5 \%$ had worked for more than 10 years. The findings therefore established that majority of the Managers of franchised Restaurants in Nairobi Central Business District had worked for quite a while and were thus familiar with the offer quality components affecting consumption of hospitality products and services in restaurants in Kenya.

As for the time the restaurant has been in operation, results indicate that $37.5 \%$ of the restaurants have been in the industry between $0-2$ years, $37.5 \%$ for 3-5 years, and $(25 \%)$ have been operational for between 6-8 years. The research therefore established that majority of the Managers of franchised Restaurants in Nairobi Central Business District in Kenya have worked for restaurants that have been in existence in the industry for a considerable period of time. 


\subsection{Offer Components and Consumption of Products and Services}

The study sought to explore the impact of offer components on the consumption in franchised restaurants in Nairobi Central Business District, Kenya. Study results are as tabulated below:

Table 3: Offer Components

\begin{tabular}{|l|c|c|}
\hline \multicolumn{1}{|c|}{ Offer Components } & Mean & $\begin{array}{c}\text { Standard } \\
\text { deviation }\end{array}$ \\
\hline The price is better than the competing restaurants & 2.973446 & 1.276630 \\
\hline The portion size is better than the competing restaurants & 2.773844 & 1.418964 \\
\hline The food is of good quality & 2.873846 & 1.378660 \\
\hline It's convenient & 2.893213 & 1.245866 \\
\hline $\begin{array}{l}\text { It provides something unique that is valuable to clients } \\
\text { beyond simply offering a low price }\end{array}$ & 2.573549 & 1.478361 \\
\hline
\end{tabular}

Source: Research data, 2017

As for the descriptive statistics, it is clear that "the price is better", "the food is of good quality" and "it is convenient" were agreed to a great extent with a mean of 2.973446 , 2.873846 and 2.893213 respectively and a standard deviation of $1.276630,1.378660$ and 1.245866 respectively. "The portion size is better" and "it provides something unique that is valuable to clients beyond simply offering a low price" were agreed to a very great extent as factors affecting adoption of offer components as a competitive strategy in the restaurant industry in Nairobi Central Business District in Kenya. The findings on "something unique that is valuable to clients beyond simply offering a low price" agree with a study by Amor (2013) which noted that Burger King had a limited menu but it has had a focused niche of markets since. Moreover, "the portion is better" finding was related to a study by Dudovskiy (2016), where economies of scale were employed to give people products that they want in McDonalds 'Happy Meal' cliché.

5.1.1. Relationship between Offer Components and Consumption of Products and Services

Table 4: Model Summary

\begin{tabular}{|c|c|c|c|c|}
\hline Model & R & R Square & $\begin{array}{c}\text { Adjusted R } \\
\text { Square }\end{array}$ & $\begin{array}{c}\text { Std. Error of } \\
\text { estimate }\end{array}$ \\
\hline 1 & 0.735 & 0.5603 & 0.493 & 0.06309 \\
\hline
\end{tabular}

a. Predictors: (Constant), Offer Components

Source: Research data, 2017

The relationship between offer components and consumption of products and services in franchised restaurants in Nairobi Central Business District in Kenya was tested using Pearson's Correlation Coefficient (R). The results showed that offer components had a moderately positive relationship with a Pearson Correlation Coefficient of 0.735 at $5 \%$ level of significance. The value of $\mathrm{R}^{2}$ was 0.5603 indicating that $56.03 \%$ of consumption of products and services is explained by offer components. 
Table 5: ANOVA for Offer Components and Consumption of Products and Services

\begin{tabular}{|c|l|c|c|c|c|c|}
\hline \multicolumn{2}{|c|}{ Model } & $\begin{array}{c}\text { Sum of } \\
\text { Squares }\end{array}$ & Df & $\begin{array}{c}\text { Mean } \\
\text { Square }\end{array}$ & F & Sig. \\
\hline \multirow{3}{*}{1} & Regression & 45.030 & 9 & 5.003 & 7.398 & $.001^{\mathrm{b}}$ \\
\cline { 2 - 7 } & Residual & 18.103 & 70 & .259 & & \\
\cline { 2 - 8 } & Total & 63.163 & 79 & & & \\
\hline
\end{tabular}

a. Dependent Variable: Consumption of Products and Services

b. Predictors: (Constant), Offer Components

Source: Research data, 2017

From the ANOVA table above, further test at 5\% level of significance indicated that the model was significant with $\mathrm{F}$ ratio equal to 7.398 at $\mathrm{p} 0.001<0.05$. What the results showis that $71.3 \%$ of the variance (R-square) in consumption of products and services has been significantly explained by the offer components in the study. It also means the offer components are a useful predictor of consumption of products and services in franchised restaurants.

Table 6 below shows the regression coefficient between offer components and the consumption of products and services in franchised restaurants in Nairobi Central Business District in Kenya. The result shows that the model had an intercept of 0.193 and a slope of 0.547 with a $\mathrm{p}$ value of $0.001<0.05$ at $5 \%$ level of significance. This indicates that the relationship between offer components and the consumption of products and services in franchised restaurants in Nairobi Central Business District in Kenya is statistically significant.

Table 6: Coefficients

\begin{tabular}{|l|c|c|c|c|c|}
\hline \multirow{2}{*}{ Model } & \multicolumn{2}{|c|}{$\begin{array}{c}\text { Unstandardized } \\
\text { Coefficients }\end{array}$} & $\begin{array}{c}\text { Standardized } \\
\text { Coefficients }\end{array}$ & \multirow{2}{*}{ t } & \multirow{2}{*}{ sig } \\
\cline { 2 - 4 } & $\mathrm{B}$ & Std. Error & Beta & & \\
\hline (Constant) & 0.193 & 0.051 & & 3.54 & 0.001 \\
\hline Reliability on Products & 0.547 & 0.312 & 0.735 & 1.25 & .001 \\
\hline
\end{tabular}

a. Dependent Variable: Consumption of Products and Services

Source: Research data, 2017

\section{Conclusions}

The research employed a sample of 325 respondents from the chosen restaurants to whom the questionnaires were issued. The research aimed at restaurants in the Central Business District in Nairobi, Kenya. The study's main objective was to explore the offer components affecting consumption of hospitality products and services in franchised restaurant in the Central Business District in Kenya.

Offer Components affecting consumption of hospitality products and services in franchised restaurants in Kenya's central business district, Nairobi, are critical factors in business strategies adopted by franchised restaurant businesses in Kenya. The study shows that in franchised restaurant businesses in Kenya, offer components offer very strong competition. Other critical issues in franchised restaurant businesses in Kenya include responsiveness to service, tangibility on branding, and assurance of service quality. These offer components were to ensure that the franchised restaurants in Nairobi CBD offered quality output, enhanced quantity production, customers' satisfaction and amount of sales made, which made the consumption of hospitality products and services increase. 
This study revealed that most restaurants offer products according to their menu and this makes them to be reliable to customers. Additionally, offering reliable products and services affect organizations profit margins. While it is believed that offer components attract all seasonal consumers when it comes to the issue of fast food the notion changes, this may be because of the fact that most fast food restaurants serve consumers who are seasonal and most of them are one-time customers. Another issue that arises is limited concern about market share and economies of scale.

The franchised restaurants in the county are set to grow with many people buying from them because of accessibility. With the few barriers to entry, more players are set to join the industry and thus those who have formulated adequate tactics are the ones who will survive the cut throat competition.

Education level of the managers is very critical. The diploma holders tended to perform better than the degree holders because of their hands-on training and practice. The age of the manager also plays an important role because the young generation is the one visiting these restaurants and young managers can relate to their needs. The time the manager spends at a restaurant as a manager is critical. The study shows that the restaurants performing well had managers who had worked in the restaurant for 3-5 years.

One of the tactics that is set to determine the winners and losers in the industry is price. The price must be affordable to the target market, although not too low because it would make the customers doubt the quality of the product. The products must be of a quality which can survive the test of time. In this case those who want to make money quickly by compromising quality are set to lose since customers will be in a position to blacklist them and sooner or later they will run out of business.

Customer service is also very important for the survival of the restaurant business in Nairobi CBD. This includes getting recommendations from customers for what they want; ensure that they supply customers with quick service and also the ability to provide after sale services. This is important because when customers are treated well they feel appreciated and will be in a position to come back again as well as bring other customers along.

\subsection{Further study}

To ensure that comprehensive strategies are used in the franchised restaurants, other studies should be done in other sectors such as the fast food restaurants. This will ensure that the relevant authorities be in a position to take the relevant action in the restaurant industry based on these and other findings.

\section{References}

1. Amor, A. (2013). McDonald's Competitive Strategy. Munich: GRIN Verlag GmbH.

2. Arlen, C. (2008). The 5 service dimensions all customers care about. Service Performance Inc., 10-15.

3. Dudovskiy, J. (2016, february 8). Research Methodology. McDonalds Business Strategy and Competitive Advantage, 12.

4. Estelle, V. (2016). Nairobi's central location makes it a hub for high class hotels in Africa. How we made it in Africa, 10-14.

5. George, L. O. (2016, June 18). Africa Hospitality industry is on truck. African Travel Times magazine, 5-11.

6. Gikonyo, L., Berndt, A., \& Wadawi, J. (2015). Critical Success Factors for Franchised Restaurants Entering the Kenyan Market: Franchisors' Perspective. SAGE Open, 5(4), 1-8. https://doi.org/10.1177/2158244015614378 
7. Malinda, C. (2013). Franchise Kenya report. pdf. Washington DC: US department of commerce.

8. Mendelsohn, E. (2004). The guide to franchising (7th ed.). London, England: Thomson Learning.

9. Michira, M. (2016, february 4 th). End of era as Kenchic bows out of fast food business to focus on processing. The standard digital, 3.

10. Mulupi, D. (2014). Restauranteur on why he is leaving KFC Kenya to rebuild the Kengeles Brand. How we made it in Africa, 4-6.

11. Munyaka, C. M. (2016). Application of Porter's Generic Strategies in Kenya's

12. Parasuraman, A., Zeithaml, V., \& Berry, L. (1998). SERVQUAL: a multi-item form of measuring consumer perceptions of the service quality. Journal of retailing, 64(1), 1240.

13. Salvador, C., Rebolloso, E., Fernández-Ramírez, B., \& del Pilar Cantón, M. (2007). Service price components and their relationship with customer satisfaction. Journal of Revenue and Pricing Management, 6(1), 40-50. https://doi.org/10.1057/palgrave.rpm.5160057

14. Samanani, A. (2013, June 12th). How we made it in Africa. (D. Mulupi, Interviewer)

15. Nicholas, A., \& Quinn, B. (2002). International retail divestment. International Journal of Retail \& Distribution Management, 30(2), 112125. https://doi.org/10.1108/09590550210418137

16. Tyre, K. H., \& Han, P. H. (2015). 3 Major challenges of franchising in Africa. New York: law360.

17. Wambura, C.W. (2012). Strategies adopted by Nairobi Java house to gain Competitive advantage. (Masters' theses). University of Nairobi, Nairobi.

18. Wanja, L. (2015). Strategic Management Practices Applied by Food Franchises in Nairobi City County Kenya to Enhance Performanc. (Masters' theses), University of Nairobi, Nairobi.

Received: 15 April 2019; Sent for revision: 18 May 2019; Accepted: 25 May 2019 